\title{
Carbon budget of tropical forests in Southeast Asia and the effects of deforestation: an approach using a process-based model and field measurements
}

\author{
M. Adachi ${ }^{1}$, A. Ito ${ }^{1}$, A. Ishida ${ }^{2}$, W. R. Kadir ${ }^{3}$, P. Ladpala ${ }^{4}$, and Y. Yamagata ${ }^{1}$ \\ ${ }^{1}$ Center for Global Environmental Research, National Institute for Environmental Studies, \\ 16-2 Onogawa Tsukuba, Ibaraki 305-8506, Japan \\ ${ }^{2}$ Center for Ecological Research, Kyoto University 509-3-2 Hirano Otsu, Shiga 520-2113, Japan \\ ${ }^{3}$ Forest Research Institute Malaysia, 52109 Kepong, Selangor Darul Ehsan, Malaysia \\ ${ }^{4}$ Department of National Park, Wildlife and Plant Conservation, Chatuchak, Bangkok 10900, Thailand
}

Received: 26 November 2010 - Published in Biogeosciences Discuss.: 21 March 2011

Revised: 24 August 2011 - Accepted: 25 August 2011 - Published: 20 September 2011

\begin{abstract}
More reliable estimates of the carbon (C) stock within forest ecosystems and $\mathrm{C}$ emission induced by deforestation are urgently needed to mitigate the effects of emissions on climate change. A process-based terrestrial biogeochemical model (VISIT) was applied to tropical primary forests of two types (a seasonal dry forest in Thailand and a rainforest in Malaysia) and one agro-forest (an oil palm plantation in Malaysia) to estimate the $\mathrm{C}$ budget of tropical ecosystems in Southeast Asia, including the impacts of land-use conversion. The observed aboveground biomass in the seasonal dry tropical forest in Thailand $\left(226.3 \mathrm{tC} \mathrm{ha}^{-1}\right)$ and the rainforest in Malaysia $\left(201.5 \mathrm{tC} \mathrm{ha}^{-1}\right)$ indicate that tropical forests of Southeast Asia are among the most Cabundant ecosystems in the world. The model simulation results in rainforests were consistent with field data, except for the NEP, however, the VISIT model tended to underestimate $\mathrm{C}$ budget and stock in the seasonal dry tropical forest. The gross primary production (GPP) based on field observations ranged from 32.0 to $39.6 \mathrm{tC} \mathrm{ha}^{-1} \mathrm{yr}^{-1}$ in the two primary forests, whereas the model slightly underestimated GPP (26.5-34.5 $\left.\mathrm{tC} \mathrm{ha}^{-1} \mathrm{yr}^{-1}\right)$. The VISIT model appropriately captured the impacts of disturbances such as deforestation and land-use conversions on the $\mathrm{C}$ budget. Results of sensitivity analysis showed that the proportion of remaining residual debris was a key parameter determining the soil $\mathrm{C}$ budget after the deforestation event. According to the model simulation, the total $\mathrm{C}$ stock (total biomass and soil C) of
\end{abstract}

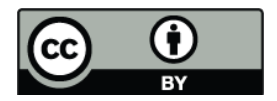

Correspondence to: M. Adachi (adachi.minaco@nies.go.jp) the oil palm plantation was about $35 \%$ of the rainforest's C stock at $30 \mathrm{yr}$ following initiation of the plantation. However, there were few field data of $\mathrm{C}$ budget and stock, especially in oil palm plantation. The $\mathrm{C}$ budget of each ecosystem must be evaluated over the long term using both the model simulations and observations to understand the effects of climate and land-use conversion on $\mathrm{C}$ budgets in tropical forest ecosystems.

\section{Introduction}

More detailed estimations of the carbon (C) stocks within forest ecosystems and of $\mathrm{C}$ emissions induced by deforestation are important environmental research goals. According to various estimates, $\mathrm{C}$ emission from land-use change accounts for about $12 \%$ (van der Werf et al., 2009) or $20 \%$ (IPCC, 2007) of the total anthropogenic emissions worldwide. Numerous studies have evaluated the amount of $\mathrm{C}$ emission due to deforestation around the world using various models (Cramer et al., 2004; Huang et al., 2008; Kato et al., 2009; McGuire et al., 2001; Ramankutty et al., 2007; Shevliakova et al., 2009). To evaluate the annual C emission from land-use change, several models considered the different decay rates of harvested forest products based on the method of Houghton et al. (1983). Cramer et al. (2004) reported that $\mathrm{C}$ emission due to land-use change had a great uncertainty in Southeast Asia; Houghton (1999) estimated the value as $1.08 \mathrm{Gt} \mathrm{C} \mathrm{yr}^{-1}$, whereas the estimate of Cramer et al. (2004) was $0.30-0.49 \mathrm{GtC} \mathrm{yr}^{-1}$. Model simulations suggested that, despite uncertainties in the deforestation area,

Published by Copernicus Publications on behalf of the European Geosciences Union. 
a large amount of $\mathrm{C}$ would be released through deforestation in the future (Cramer et al., 2004). Kato et al. (2009) estimated that $44.4 \mathrm{GtC}$ had been emitted globally over the prior $100 \mathrm{yr}$, and the global $\mathrm{C}$ emission induced by land-use change was estimated as $0.5 \mathrm{GtC} \mathrm{yr}^{-1}$ in the 1980s. On a regional scale, many model simulations of the impacts of deforestation have specifically examined Amazonian forests (e.g., Malhi et al., 2008), whereas fewer studies have investigated the impacts of land-use change on the $\mathrm{C}$ stocks of ecosystems in Southeast Asia.

According to the Global Forest Resource Assessment conducted in 2010 (FAO, 2010), tropical forests (excluding rubber plantations) accounted for 19.3 million ha. Between 1990 and 2007, the area of tropical forests in Malaysia had decreased by 1.2 million ha. Those deforested areas have been converted mostly into farmland or agro-forests. Especially the area of oil palm plantations in Malaysia increased rapidly, from 2.0 million ha in 1990 to 4.2 million ha in 2007 (FAO, 2010). Consequently, Malaysia has become one of the major palm oil-producing countries, producing more than $40 \%$ of the world's supply (Fitzherbert et al., 2008).

A more detailed understanding of the impacts of deforestation on the net $\mathrm{C}$ budget of ecosystems in Southeast Asia is needed for $\mathrm{C}$ management and mitigation of climate change. In the present study, we adopted a process-based terrestrial biogeochemical model, Vegetation Integrative SImulator for Trace gases (VISIT), to estimate the $\mathrm{C}$ budget of primary tropical forest ecosystems and the impacts of land-use conversion, while considering both instantaneous emissions from rapidly released $\mathrm{C}$ from pools and gradual decomposition of slowly released $\mathrm{C}$ from pools, such as coarse woody debris. The change in vegetation structure (e.g., amount of biomass and canopy leaves), plant ecophysiological properties (e.g., photosynthetic capacity and respiration), and soil biogeochemical properties (e.g., soil texture) are important factors to include in models for a more detailed assessment. Furthermore, in the case of cropland, we must consider C exports through crop harvests when evaluating the net ecosystem C budget (e.g., net biome production (NBP): Chapin III et al., 2006; Poulter et al., 2010). The objectives of the present study were to: (1) clarify the similarities and differences between a wet and dry tropical forest to evaluate the potential applicability of the VISIT model, (2) compare the model simulations of tropical ecosystems with field data and modify the VISIT model accordingly, and (3) evaluate the C budget before and after land-use conversion in Malaysia using the VISIT model. Based on our findings, we discuss the potential applicability of the VISIT model and some problems related to its application in Southeast Asia.

\section{Materials and methods}

\subsection{Site description}

The present study was conducted in two primary forests, a rainforest (RF) in Malaysia and a dry evergreen forest (DEF) in Thailand, and in an oil palm plantation (OPP) in Malaysia (Fig. 1). The RF was in the Pasoh Forest Reserve $\left(2^{\circ} 5^{\prime} \mathrm{N}, 102^{\circ} 18^{\prime} \mathrm{E}\right)$, and OPP was adjacent to the reserve. The annual mean air temperature in the Pasoh area was $27.1^{\circ} \mathrm{C}$ (1992-1994; Bekku et al., 2003), and the monthly mean maximum and minimum air temperatures were $32.5^{\circ} \mathrm{C}$ and $22.5^{\circ} \mathrm{C}$ in the Pasoh area, respectively (1991-1997; Manokaran et al., 2004). The annual precipitation ranged from 1450 to $2341 \mathrm{~mm}$ (1995-2000; Malaysian Meteorological Services). The RF is a tropical evergreen forest dominated by Dipterocarpaceae, with total aboveground biomass of $403 \mathrm{t}$ dry matter ha ${ }^{-1}$ in 1998 (Hoshizaki et al., 2004). At OPP, oil palms (Elaeis guineensis) were planted first around 1976 and clear-cut in October 2001; palm seedlings were replanted in 2002 for the second rotation. The soil type in RF was classified as Haplic Acrisol (Yamashita et al., 2003) and the soil texture at 5-cm depth was heavy clay in RF and sandy clay loam in OPP (Adachi et al., 2005), respectively. Soil $\mathrm{C}$ contents at 5-cm depth in RF and OPP were $2.92 \%$ and $1.55 \%$, respectively (Adachi et al., 2006).

The DEF was located at the Sakaerat Environmental Research Station $\left(14^{\circ} 30^{\prime} \mathrm{N}, 101^{\circ} 55^{\prime} \mathrm{E}\right)$. The annual mean temperature was $24.1^{\circ} \mathrm{C}$, and the monthly mean maximum and minimum air temperatures were $28.1^{\circ} \mathrm{C}$ and $21.0^{\circ} \mathrm{C}$, respectively (2001-2003; from the AsiaFlux Database). The annual precipitation was $1733 \mathrm{~mm}$ in 2003 (Ishida et al., 2006). Dipterocarpaceae, Moraceae and Meliaceae trees are dominant (Yamashita et al., 2010). The total aboveground biomass was $452.6 \mathrm{t}$ dry matter ha ${ }^{-1}$ in 1993 (Kanzaki et al., 2009). The soil type in DEF was classified as Orthic Acrisols (FAO/UNESCO: Sakurai et al., 1998), and the soil C content was $2.48 \%$ at 5-cm depth (Yamashita et al., 2010).

\subsection{Model overview}

A process-based terrestrial biogeochemical model (VISIT) was developed based on a simple $\mathrm{C}$ cycle model (SimCYCLE: Ito and Oikawa, 2002; Kato et al., 2009), in which the atmosphere-ecosystem exchange and internal dynamics of $\mathrm{C}$ are simulated at a daily time step. The VISIT model was originally developed for a cool-temperate deciduous broadleaved forest (Inatomi et al., 2010; Ito, 2010a), and it simulates long-term $\mathrm{C}$ dynamics including the impacts of forest disturbance (temperate forest: Ito et al., 2005). The ecosystem budget of $\mathrm{CO}_{2}$, that is, the net ecosystem production (NEP), is obtained as the difference between photosynthetic uptake (gross primary production, GPP) and respiratory emissions from plants and microbes. The $\mathrm{CO}_{2}$ efflux from the soil surface, that is, the soil respiration (SR), 


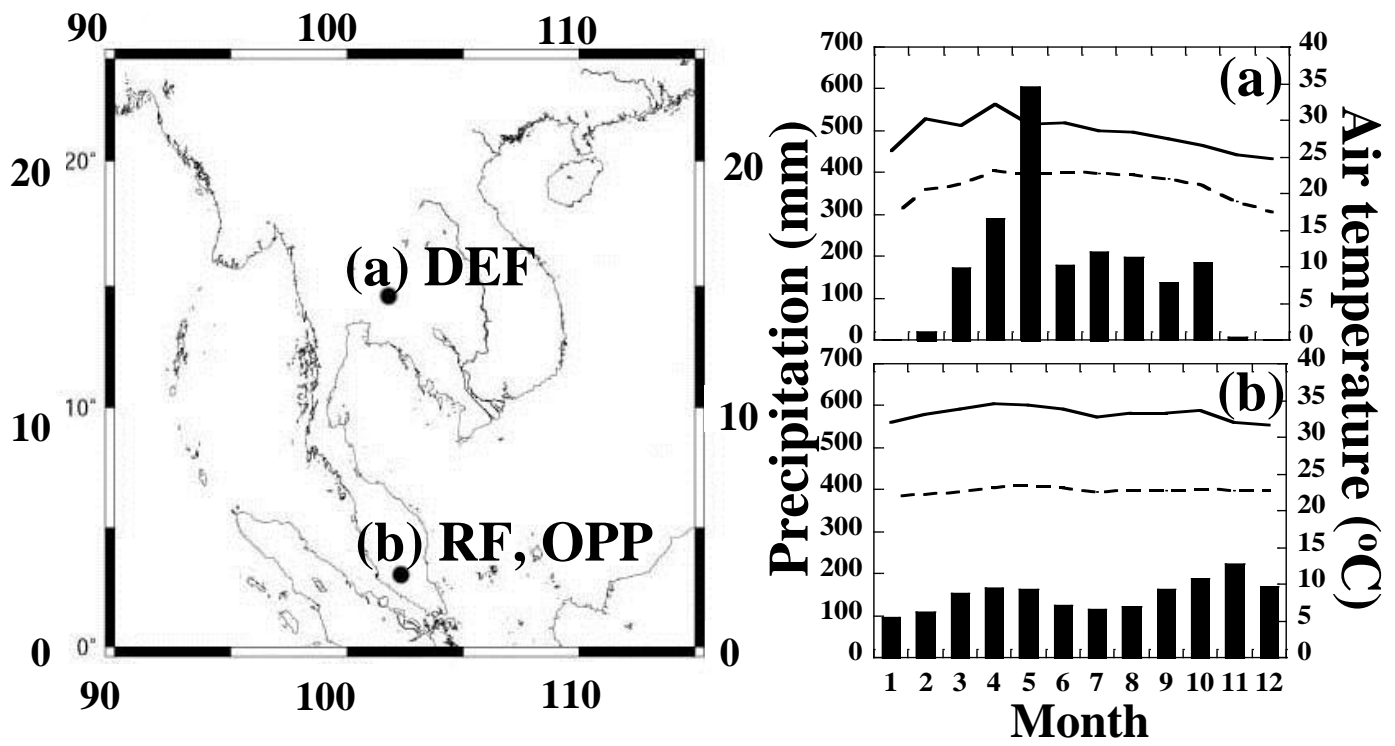

Fig. 1. Locations of the dry evergreen forest (DEF) in Thailand and the rainforest (RF) and the oil palm plantation (OPP) in Peninsular Malaysia. Climate data for (a) DEF (2001-2003, from the AsiaFlux Database) and (b) RF and OPP (1991-1997, from Manokaran et al., 2004). Solid and broken lines show the monthly means of daily maximum and minimum air temperatures, respectively; vertical bars show the monthly precipitation.

is obtained as the sum of plant root respiration and microbial heterotrophic respiration. These biogeochemical C flows are calculated based on models of the ecophysiological responses of the vegetation to environmental parameters.

Figure 2 shows an overview of the VISIT model, which was developed based on Sim-CYCLE with three main improvements. First, the ecosystem $\mathrm{C}$ stock is divided into more detailed compartments in the VISIT model. For example, understory plants $\left(\mathrm{C}_{3}\right.$ grasses and shrubs) are explicitly separated from canopy trees, and litter and humus $\mathrm{C}$ stocks are subdivided into multiple compartments with different turnover times. As a result, the ecosystem structure of the $\mathrm{C}$ stock is represented by four sectors: canopy trees, understory plants, litter and humus (Fig. 2a). Second, the VISIT model was able to evaluate the impacts of forest disturbance and land-use change (Fig. 2b). To evaluate the effect of land-use conversion from a primary forest to an oil palm plantation, we incorporated three processes in the model: (1) removing the existing aboveground forest biomass (wood harvest), (2) residual (or leaving) woody and root debris (residual debris), and (3) planting of oil palm seedlings. The year of disturbance and planting of oil palm seedlings can be set for anytime, but this event occurred only once in this model. Because oil palm seedlings were replanted in 2002 for second rotation in OPP, the disturbance event from forest to oil palm plantation in the VISIT model was set for 2001 in Fig. 9c. After planting, oil palm seedlings are managed as they grow in the VISIT model. Once a tree is $5 \mathrm{yr}$ old, $5 \%$ of its leaves are pruned each year and added to the litter $\mathrm{C}$ pool. Moreover, oil palm fruits are harvested from stem at $10 \mathrm{yr}$ of age in the VISIT model, accounting for a $\mathrm{C}$ loss of $3.3 \mathrm{tC} \mathrm{ha}^{-1} \mathrm{yr}^{-1}$ based on a report of palm oil yields (2.8 $\mathrm{tha}^{-1}$; Stone, 2007). Third, the VISIT model enables us to evaluate atmosphereecosystem exchange of not only $\mathrm{CO}_{2}$, but also other greenhouse gases $\left(\mathrm{CH}_{4}\right.$ and $\mathrm{N}_{2} \mathrm{O}$; Inatomi et al., 2010); however, this exchange is not discussed in the present study.

\subsection{Ecophysiological and soil parameters used in the model}

Representative ecophysiological parameters of the primary forests (DEF and RF) and OPP are presented in Table 1. The single-leaf photosynthetic rate was calculated using the maximum photosynthetic rate under light-saturation, the lightuse efficiency and the photosynthetic photon flux density (Ito and Oikawa, 2002). Although the VISIT model does not simulate the stem density explicitly, the difference between the forest and oil palm canopies can be captured reasonably well as the differences in photosynthetic capacities and allocation coefficients. The soil characteristics of DEF, $\mathrm{RF}$, and OPP were represented by three soil parameters (bulk density, and sand and clay contents) obtained from previous reports and field measurements (Table 2). These parameters are important for characterising hydrological and biogeochemical properties to evaluate the $\mathrm{C}$ stock of the soil and $\mathrm{C}$ sequestration following the land-use change. Soil solid volumes within $100-\mathrm{ml}$ soil core samples were measured using a three-phase meter (DIK-1121; Daiki Rika Kogyo Co. Ltd., Konosu, Japan). The fresh weight of each sample was measured and the material was dried at $105^{\circ} \mathrm{C}$ 
(a) Primary forest

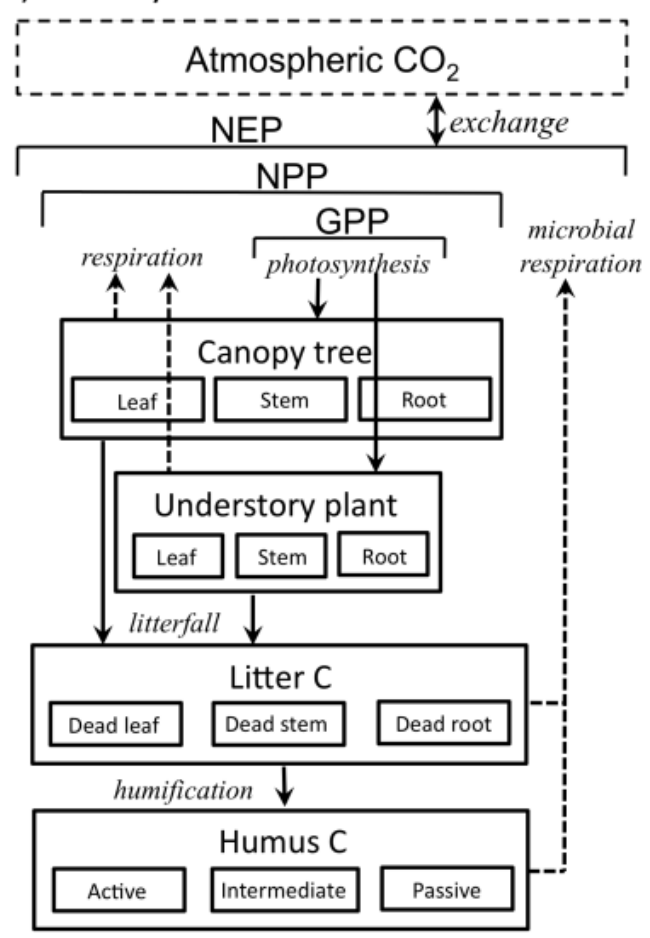

(b) Land-use change + oil palm plantation

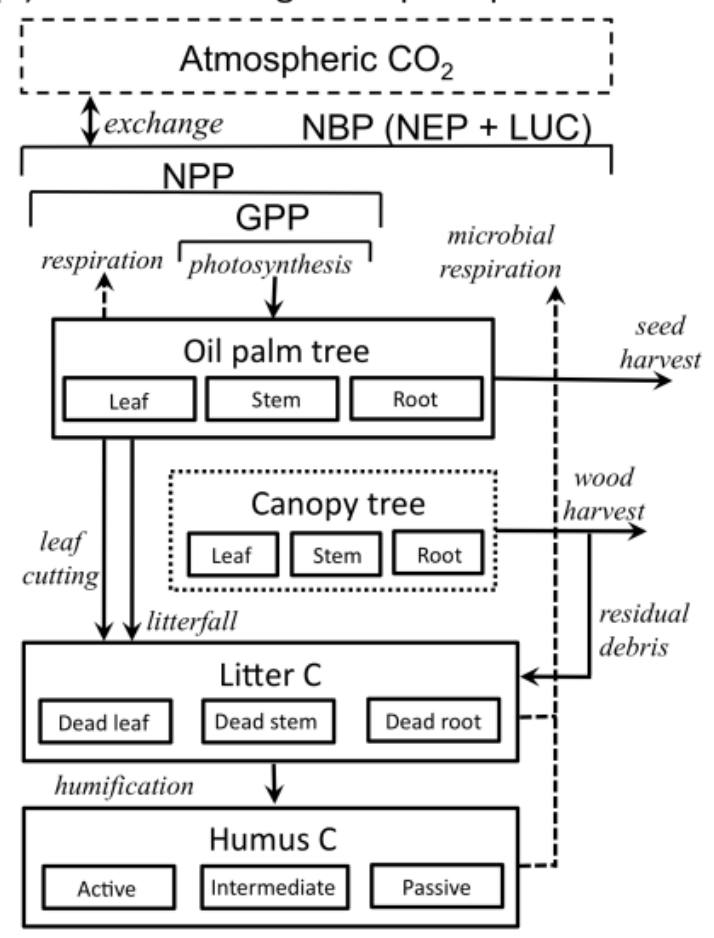

Fig. 2. An overview of the VISIT model for (a) primary forest and (b) land-use change (LUC) from forest to oil palm plantation. The C flux among the compartments and the atmosphere represent net ecosystem production (NEP), net primary production (NPP) and gross primary production (GPP); net biome production (NBP) consists of NEP and carbon flux from LUC.

Table 1. VISIT model parameters for the primary forest (dry evergreen forest and rainforest) and oil palm plantation.

\begin{tabular}{|c|c|c|c|}
\hline Parameters & Unit & Forest & Oil palm plantation \\
\hline Maximum photosynthetic rate & $\mu \mathrm{mol} \mathrm{CO} \mathrm{m}^{-2} \mathrm{~s}^{-1}$ & 20 & 20 \\
\hline Leaf allocation coefficient & fraction & 0.1 & 0.2 \\
\hline Aboveground allocation coefficient & fraction & 0.55 & 0.60 \\
\hline Specific leaf area & $\mathrm{cm}^{2} \mathrm{~g}^{-1}$ & 170 & 150 \\
\hline Stem growth respiration coefficient & fraction allocated carbon & 0.25 & 0.18 \\
\hline Root growth respiration coefficient & fraction allocated carbon & 0.35 & 0.32 \\
\hline leaf maintenance respiration coefficient & 0.001 fraction biomass $\left(15^{\circ} \mathrm{C}\right)$ & 1.57 & 1.30 \\
\hline Sapwood maintenance respiration coefficient & 0.001 fcation biomass $\left(15^{\circ} \mathrm{C}\right)$ & 0.25 & 0.06 \\
\hline Fine root maintenance respiration coefficient & 0.001 fcation biomass $\left(15^{\circ} \mathrm{C}\right)$ & 0.35 & 0.60 \\
\hline Heartwood maintenance respiration coefficient & 0.001 fcation biomass $\left(15^{\circ} \mathrm{C}\right)$ & 0.014 & 0.008 \\
\hline Coarse root maintenance respiration coefficient & 0.001 fcation biomass $\left(15^{\circ} \mathrm{C}\right)$ & 0.055 & 0.150 \\
\hline Harvest leaf every year ${ }^{1}$ & $\%$ of leaves $\mathrm{yr}^{-1}$ & - & 5.0 \\
\hline Harvest oil palm (from stem) every year ${ }^{2}$ & $\mathrm{tCha}^{-1} \mathrm{yr}^{-1}$ & - & 3.3 \\
\hline
\end{tabular}

${ }^{1}$ Conducted 5 yr after planting, ${ }^{2}$ Conducted $10 \mathrm{yr}$ after planting.

for $48 \mathrm{~h}$. The dry weight was measured to calculate the volumes of the water and gas phases within the core samples (Hillel, 1998).

\subsection{Input data for the VISIT model}

For each site, we repeatedly conducted a spin-up calculation for $2000 \mathrm{yr}$ to create appropriate initial states of ecosystem C pools and budgets using the climate data for 19482008. Moisture conditions such as soil water content, which 
Table 2. Soil parameters measured at the dry evergreen forest (DEF) in Thailand and the rainforest (RF) and oil palm plantation (OPP) in Malaysia.

\begin{tabular}{lcccc}
\hline Site Vegetation & \multicolumn{2}{c}{ Sakaerate, Thailand } & & \multicolumn{2}{c}{ Pasoh, Malaysia } \\
\cline { 2 - 2 } \cline { 5 - 5 } & Dry evergreen forest & & Evergreenforest & Oil palmplantation \\
\hline Bulk density & $1.05^{1}$ & & $0.74^{3}$ & $1.06^{3}$ \\
Sand content $(\%)$ & $61.2^{2}$ & & $16.6^{1}$ & $67.2^{1}$ \\
Clay content $(\%)$ & $24.9^{2}$ & & $57.8^{1}$ & $21.0^{1}$ \\
\hline
\end{tabular}

${ }^{1}$ Measured in the present study, ${ }^{2}$ Yamashita et al. (2010), ${ }^{3}$ Yashiro et al. (2007)

Table 3. Climate parameters from NCEP/NCAR used in the VISIT model.

\begin{tabular}{ll}
\hline Parameters & Unit \\
\hline Air temperature at $2 \mathrm{~m}$ hight & $\mathrm{K}$ \\
Specific humidity at $2 \mathrm{~m}$ & $\mathrm{~kg} \mathrm{~kg}^{-1}$ \\
Precipitation & $\mathrm{kg} \mathrm{m}^{-2} \mathrm{~s}^{-1}$ \\
Downward shortwave radiation & $\mathrm{W} \mathrm{m}{ }^{-2}$ \\
Cloud cover & $\%$ \\
Soil surface temperature & $\mathrm{K}$ \\
Soil temperature at $0-10 \mathrm{~cm}$ depth & $\mathrm{K}$ \\
Soil temperature at $10-200 \mathrm{~cm}$ depth & $\mathrm{K}$ \\
Soil temperature at $300 \mathrm{~cm}$ depth & $\mathrm{K}$ \\
$U$ wind (component of west-east) & $\mathrm{m} \mathrm{s}^{-1}$ \\
$V$ wind (component of north-south) & $\mathrm{m} \mathrm{s}^{-1}$ \\
Air pressure (Pa) & $\mathrm{Pa}$ \\
\hline
\end{tabular}

determine the effect of water stress on plant production and soil decomposition, are simulated in a hydrological subscheme. In the submodel, soil moisture content is calculated from the water-budget equation using precipitation data (input), and estimated evapotranspiration and runoff discharge (outputs) are estimated in another submodel (Ito and Oikawa, 2002). The VISIT model incorporates the increase of background atmospheric $\mathrm{CO}_{2}$ concentration from $310 \mathrm{ppmv}$ in 1948 to 392 ppmv in 2008 , leading to a $\mathrm{CO}_{2}$ fertilization effect on the photosynthesis rate.

The model simulations were conducted at a daily time step, using daily average meteorological forcing data (Table 3). Ito and Oikawa (2002) and Ito et al. (2006) indicated the details of calculation methods for radiation and water budget of the Sim-CYCLE model, and these methods were used in the VISIT model. For this study, daily data were derived from a reanalysis global climate dataset produced by the US National Centers for Environmental Prediction and the US National Center for Atmospheric Research (NCEP/NCAR; Kistler et al., 2001) for the period from 1 January 1948 to 31 December 2008. Although these data have a coarse spatial resolution, they provide a representative long-term time series of meteorological conditions.
Because the NCEP/NCAR data represent large-scale average meteorological conditions, there remain several biases in comparison with observational data at specific sites. Figure 3 shows a comparison between monthly precipitation according to NCEP/NCAR data and field observation at RF and DEF. Based on the discrepancies, NCEP/NCAR precipitation data were corrected using the differences of monthly mean precipitation from 2001 to 2003 in DEF and 1991 to 1997 in RF (Fig. 3). Moreover, the NCEP/NCAR precipitation data from 1948 to 1954 contain a clear low-precipitation bias due to insufficient observational data. Therefore, the data during that period were replaced by the daily averages for 1955-2008 in DEF and 1955-1978 in RF. Figure 4 shows the annual mean air temperature and corrected precipitation pattern in DEF and RF from 1948 to 2008. On the other hand, annual mean air temperature by NCEP/NCAR data was not greatly different with the in-situ data.

\subsection{Sensitivity analysis of $\mathrm{C}$ flux induced by land-use change}

When a clear-cut occurs at a certain stand age in the VISIT model, it is assumed that all canopy trees are cut and exported, except for a part of the stems, leaves and roots that are left behind as residual woody debris. The VISIT model is able to define the individual ratios of remaining stems, leaves and roots as residual debris. Houghton et al. (1983) reported various conversion ratios for the amount of $\mathrm{C}$ stored in products obtained from tropical ecosystems, that is released into the atmosphere: $33 \%$ of total biomass $\mathrm{C}$ remained in the soil as residual woody debris, and the other $67 \%$ was removed as wood harvest. We assumed that $60 \%$ of harvested wood C is consumed and returned to the atmosphere within $1 \mathrm{yr}$ and that the remaining $40 \%$ is decomposed over the course of the next $9 \mathrm{yr}$ (i.e., all is decomposed after $10 \mathrm{yr}$ ). Residual debris was added to soil $\mathrm{C}$ and its decomposition rate was assumed to be the same as the litter decomposition rate. Therefore, the soil respiration rate in OPP included the respiration of oil palm roots and microbes, which consumed the residual debris and oil palm litter. In the present study, the proportions of the stem, leaf and root $\mathrm{C}$ pools were changed individually from 0 to $100 \%$. 
Table 4. Comparisons of gross primary production (GPP), net ecosystem production (NEP), soil respiration rate (SR) and aboveground biomass carbon (AGB) between the VISIT model simulations and field measurements. AGB carbon values were estimated as half of the aboveground biomass.

\begin{tabular}{|c|c|c|c|c|c|c|c|c|c|}
\hline \multirow[b]{2}{*}{$\mathrm{tCha}^{-1} \mathrm{yr}^{-}$} & \multicolumn{3}{|c|}{ DEF site } & \multicolumn{3}{|c|}{ RF site } & \multicolumn{3}{|c|}{ OPP site } \\
\hline & VISIT $^{1}$ & Field data & Year of data & VISIT $^{1}$ & Field data & Year of data & VISIT $^{1}$ & Field data & Year of data \\
\hline \multirow[t]{2}{*}{ GPP } & 32.5 & $35.6^{2}$ & 2002 & 26.5 & $32.6^{4}$ & 2003 & 6.3 & nd & Average of $1-10 \mathrm{yr}$ old \\
\hline & 31.8 & nd & 2004 & 31.5 & $32.0^{4}$ & 2005 & 25.2 & nd & Average of $21-30 \mathrm{yr}$ old \\
\hline \multirow[t]{2}{*}{ NEP } & 1.0 & $-1.8^{2}$ & 2002 & -1.9 & $-0.4^{4}$ & 2003 & -6.4 & $1.06^{7}$ & $5 \mathrm{yr}$ old \\
\hline & 2.5 & $0.9^{2}$ & 2003 & -1.9 & $2.4^{4}$ & 2004 & 5.2 & nd & Average of $11-20 \mathrm{yr}$ old \\
\hline SR & 18.2 & nd & 2001 & 20.1 & $18.1^{5}$ & 2001 & 14.9 & $14.4^{5}$ & 2001 \\
\hline AGB & 160.4 & $226.3^{3}$ & 1993 & 182.8 & $201.5^{6}$ & 1998 & 34.9 & $33.9^{8}$ & $27.5 \mathrm{yr}$ old \\
\hline
\end{tabular}

${ }^{1}$ Same year or period as field data; ${ }^{2}$ Hirata et al. (2008); ${ }^{3}$ Half of aboveground biomass; Kanzaki et al. (2009); ${ }^{4}$ Kosugi et al. (2008); ${ }^{5}$ Adachi and Koizumi (2009);

${ }^{6}$ Half of aboveground biomass; Hoshizaki et al. (2004); ${ }^{7}$ Melling et al. (2008); ${ }^{8}$ Half of aboveground biomass; Corley and Tinker (2003); nd: no data

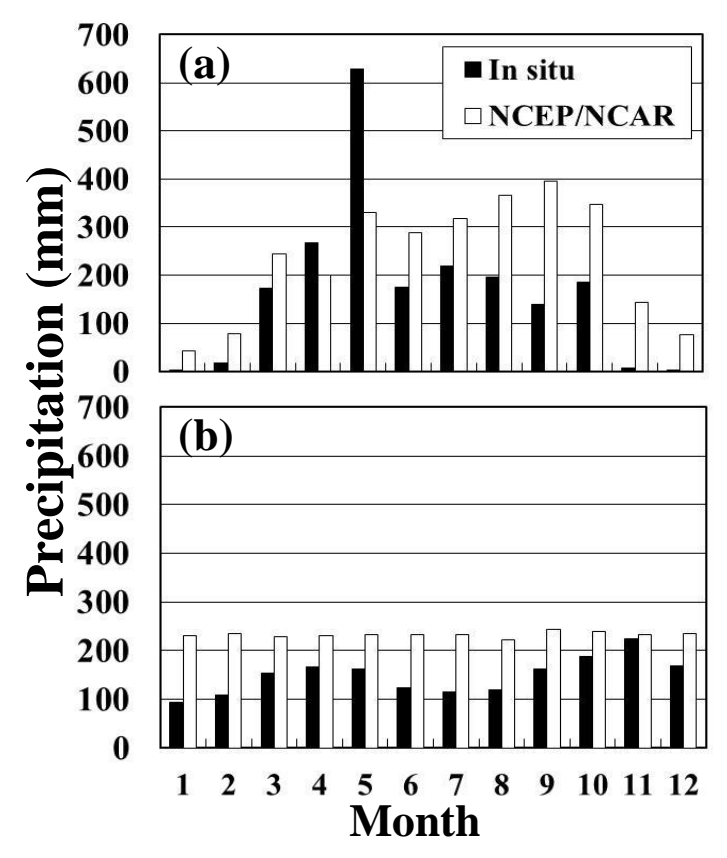

Fig. 3. Comparison of observed monthly precipitation data and that from the US National Centers for Environmental Prediction and the US National Center for Atmospheric Research (NCEP/NCAR) in (a) dry evergreen forest (DEF) from 2001 to 2003 and (b) rainforest (RF) from 1991 to 1997.

\subsection{Validation data for the VISIT model}

The diurnal patterns of GPP from 2003 to 2005 were compared with GPP data gathered by two satellites. Data subsets for RF and DEF were obtained from the Moderate Resolution Imaging Spectrometer (MODIS), Collection 5, onboard the Terra and Aqua satellites, target area were $3 \mathrm{~km}^{2}$ at a $1-\mathrm{km}$ resolution. The data were provided by the US Oak Ridge

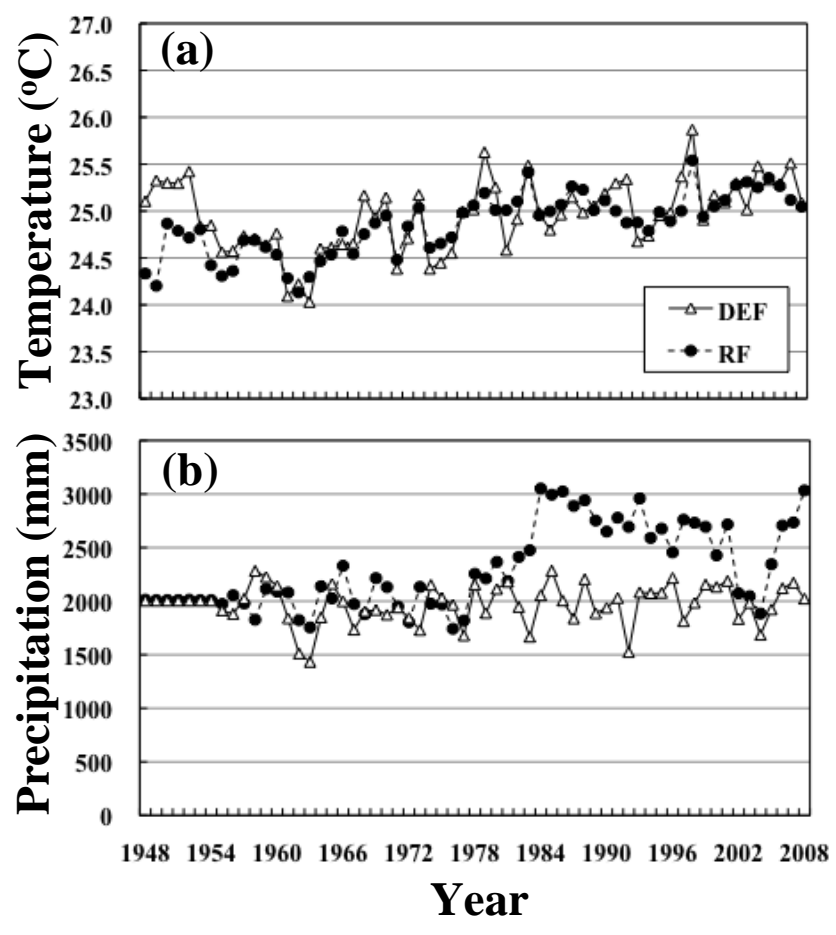

Fig. 4. Annual mean (a) air temperatures and (b) precipitation in dry evergreen forest (DEF) in Thailand and rainforest (RF) in Malaysia based on NCEP/NCAR data from 1948 to 2008. Precipitation data were corrected using the observed monthly mean precipitation (Fig. 3).

National Laboratory (http://daac.ornl.gov/MODIS/). Terra and Aqua pass the equator each day at 10:30 and 13:30 LT, respectively. Data that passed the quality assurance testing by the US Oak Ridge National Laboratory were used for the comparison. 

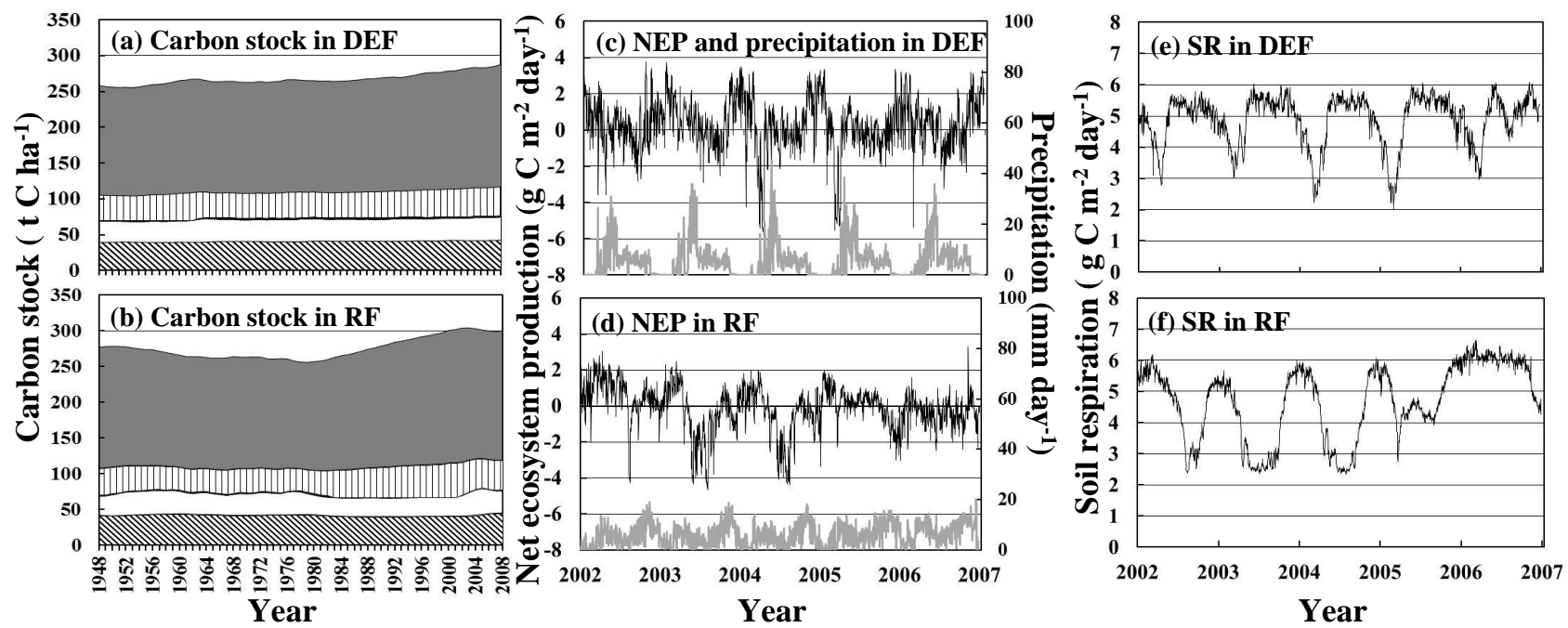

Fig. 5. Temporal variations in $(\mathbf{a}, \mathbf{b})$ carbon stock, $(\mathbf{c}, \mathbf{d})$ net ecosystem production (NEP: black line) and daily precipitation (gray line) and $(\mathbf{e}, \mathbf{f})$ soil respiration (SR) in dry evergreen forest (DEF) in Thailand (top) and the rainforest (RF) in Malaysia (bottom) simulated by the VISIT model. The subclasses of $\mathrm{C}$ stock are aboveground biomass of canopy tree (gray), belowground biomass (vertical), understory plant biomass (black), dead biomass and detritus (litter; white) and humus (diagonal line) from top to bottom.

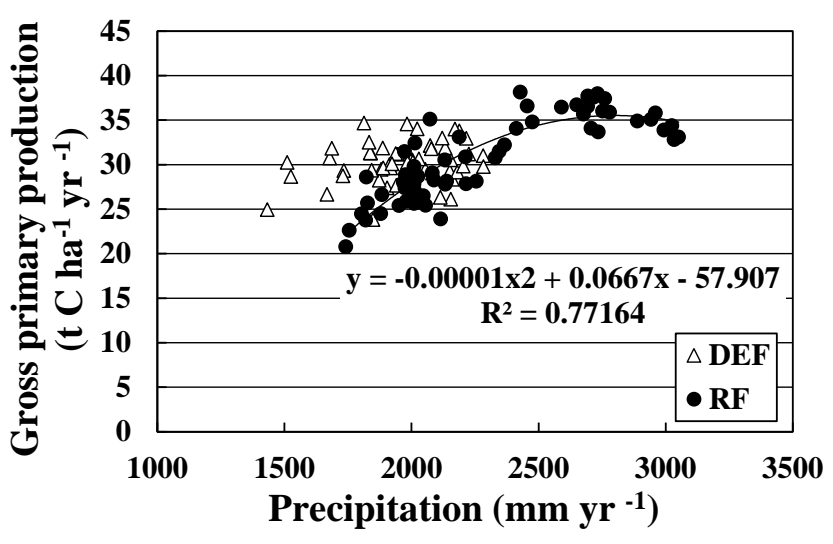

Fig. 6. The relationship between annual precipitation and gross primary production estimated by the VISIT model.

\section{Results}

\subsection{C budget in the primary forests}

The seasonal variations in original NCEP/NCAR data of precipitation were lower than the field measurement, especially in RF (Fig. 3b). The corrected mean annual precipitations were $1967 \mathrm{~mm}$ in DEF and $2339 \mathrm{~mm}$ in RF in 1995-2008 (Fig. 4b), these rates were lower than the original NCEP/NCAR data: $2659 \mathrm{~mm}$ in DEF and $3299 \mathrm{~mm}$ in RF. The $\mathrm{C}$ stock and $\mathrm{C}$ fluxes in two primary tropical forests (DEF and RF) were simulated using the VISIT model (Fig. 5). The gradual increase of $\mathrm{C}$ stock at both sites from 1948 to 2008 (Fig. 5a, b) would be induced by the increase of atmospheric $\mathrm{CO}_{2}$ concentration, that is, by the $\mathrm{CO}_{2}$ fertilization effect. Because the ecophysiological parameters used in the model simulations were set at the same values at the two forests (Table 1), the difference in their $\mathrm{C}$ budgets were mainly attributable to the differences in air temperatures, precipitation and site-specific soil parameters. The more humid RF had a larger total C stock (canopy trees, understory plants, litter and humus, $299.7 \mathrm{t} \mathrm{Cha}^{-1}$ ) than the drier DEF $\left(287.6 \mathrm{t} \mathrm{C} \mathrm{ha}^{-1}\right)$ in 2008 . The seasonal variation in NEP was clearer in DEF than in RF (Fig. 5c, d). The standard deviation (SD) of NEP in 2002-2006 was $1.48 \mathrm{~g} \mathrm{C} \mathrm{m}^{-2}$ day $^{-1}$ in DEF and $1.26 \mathrm{~g} \mathrm{C} \mathrm{m}^{-2}$ day $^{-1}$ in RF. The SDs of SR were 0.81 and $1.19 \mathrm{~g} \mathrm{C} \mathrm{m}^{-2}$ day $^{-1}$ in DEF and RF, respectively (Fig. 5e, f). Neither daily NEP nor SR had a significant relationship with daily precipitation in DEF and RF.

Table 4 presents the forest $\mathrm{C}$ budgets for $\mathrm{DEF}$ and $\mathrm{RF}$ based on field measurements versus model estimates. As compared to tropical ecosystems in general, relatively high photosynthetic uptakes (GPP) of $32.0-39.6 \mathrm{tC} \mathrm{ha}^{-1} \mathrm{yr}^{-1}$ were observed at both sites. The model slightly underestimated GPP as $26.5-34.5 \mathrm{tC} \mathrm{ha}^{-1} \mathrm{yr}^{-1}$. The simulated aboveground biomass and GPP in 2005 were consistent with field data (Table 4). The relationship between the annual precipitation and GPP rate in RF was expressed as a quadratic equation (Fig. 6). The low simulated GPP rate in RF would have been affected by the lower precipitation from 2002 to 2004 (Figs. 4b, 6), because single-leaf photosynthetic capacity was assumed to be limited by low soil water content induced by low precipitation in the VISIT model. In DEF, aboveground biomass was underestimated by the model, although the estimated GPP was consistent with field observations. Because the net $\mathrm{C}$ budgets of the tropical forest sites were close to equilibrium, it was difficult for the model to capture the small interannual variability in NEP (Table 4). 
Table 5. Results of sensitivity analysis of the carbon flux for $2 \mathrm{yr}$ (1977-1978) and total carbon flux during 10 yr (1977-1986) after deforestation in the VISIT model. Deforestation occurred in 1976 in this simulation. Harvest rate changes and changes in the proportions of remaining leaves, stems and roots are shown.

\begin{tabular}{|c|c|c|c|c|c|c|c|c|}
\hline \multicolumn{3}{|c|}{ Proportion remaining } & \multirow[b]{2}{*}{ (a) Harvest $\left(\mathrm{tC} \mathrm{ha}^{-1}\right)$} & \multirow[b]{2}{*}{ (b) $60 \%$ of Harvest } & \multicolumn{4}{|c|}{ Cumulative $\mathrm{C}$ flux induced by land use change $\left(\mathrm{tCha}^{-1}\right)$} \\
\hline Leaf $(\%)$ & Stem $(\%)$ & $\operatorname{Root}(\%)$ & & & (c) SR in $2 \mathrm{yr}^{\mathrm{a}}$ & Total C flux ((b) + (c)) & (d) SR in $10 \mathrm{yr}^{\mathrm{b}}$ & Total C flux $((a)+(d))$ \\
\hline 100 & 100 & 100 & 0.0 & 0.0 & 74.4 & 74.4 & 209.3 & 209.3 \\
\hline 80 & 80 & 80 & 36.9 & 22.1 & 63.2 & 85.3 & 181.5 & 218.4 \\
\hline 60 & 60 & 60 & 73.8 & 44.3 & 52.1 & 96.4 & 153.8 & 227.6 \\
\hline 50 & 50 & 50 & 92.3 & 55.4 & 46.5 & 101.9 & 140.0 & 232.3 \\
\hline 40 & 40 & 40 & 110.7 & 66.4 & 40.9 & 107.3 & 126.1 & 236.8 \\
\hline 20 & 20 & 20 & 147.7 & 88.6 & 29.7 & 118.3 & 98.4 & 246.1 \\
\hline 0 & 0 & 0 & 184.6 & 110.8 & 18.5 & 129.3 & 70.7 & 255.3 \\
\hline 100 & 40.7 & 100 & 123.6 & 74.2 & 35.0 & 109.2 & 116.0 & 239.6 \\
\hline \multicolumn{3}{|c|}{ No disturbance (Forest) } & 0.0 & 0.0 & 31.6 & 31.6 & 175.9 & 175.9 \\
\hline
\end{tabular}

Disturbance year was 1976 .

Harbest carbon was assumed to be released to the atmosphere, with $60 \%$ in $1 \mathrm{yr}$ and $100 \%$ in $10 \mathrm{yr}:{ }^{\mathrm{a}} 1977$ to $1978 ;{ }^{\mathrm{b}} 1977$ to 1986 .
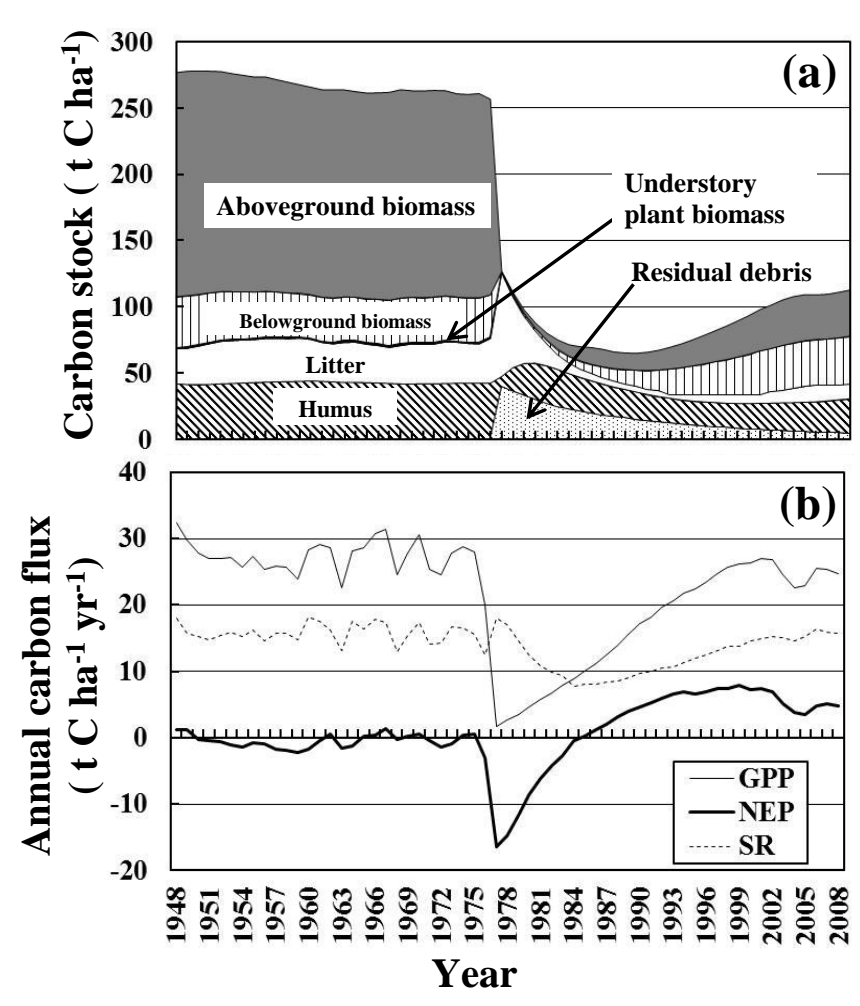

Fig. 7. Temporal variation in $\mathrm{C}$ stock (a) and $\mathrm{C}$ flux (b) within the rainforest (RF) during 1948-2008, including land-use conversion from a primary forest to oil palm plantation in 1976. The subclasses of $\mathrm{C}$ stock are aboveground biomass of canopy tree (gray), belowground biomass (vertical), understory plant biomass (black), dead biomass and detritus (litter; white), humus (diagonal line), and residual debris (dotted) from top to bottom. The subclasses of $\mathrm{C}$ flux are gross primary production (GPP; solid line), soil respiration (SR; broken line) and net primary production (NEP; bold line).

\subsection{Effect of plantation formation on $\mathrm{C}$ stock}

The VISIT model considered the impacts of land-use conversion, especially the effect of residual woody debris added to the soil $\mathrm{C}$ pool. Table 5 shows the results of a sensitivity analysis of the VISIT model for RF in terms of changes in the ratios of remaining residual debris as stem, leaf and root when a plantation is formed. Cumulative $\mathrm{C}$ flux induced by land-use change represents the sum of $\mathrm{C}$ flux from soil during a 2-yr period (1977-1978) and 10-yr period (1977-1986) plus harvested $C$ within the 1st and 10th yr, respectively. The analysis suggested that SR during the $10 \mathrm{yr}$ was lower than the no disturbance (forest) ecosystems at the some case of ratios of remaining residual debris. Usually, the $\mathrm{C}$ loss from harvest was not considered in the NBP, however, all cases of ratios of remaining residual debris served as a $\mathrm{C}$ source in the two periods when the $\mathrm{C}$ loss from harvest was added to the SR.

Figure 7 shows the temporal variations in the $\mathrm{C}$ stock and $\mathrm{C}$ flux before and after land-use conversion from a primary forest (RF) to an oil palm plantation (OPP) in 1976, as simulated by the VISIT model. Note, however, that there were few field data from OPP (Table 4). The aboveground biomass $\mathrm{C}$ in OPP was similar for field measurements and model estimates of 27.5-yr-old oil palms in 2003 and half year. However, the estimated NEP in OPP was higher than that in forest ecosystem since $10 \mathrm{yr}$-old after planting of the seedlings (Fig. 7b), our findings indicate that the total $\mathrm{C}$ stock (canopy trees, litter and humus) in OPP $\left(104.3 \mathrm{tC} \mathrm{ha}^{-1}\right)$ at $30 \mathrm{yr}$ following initiation of the plantation was about $35 \%$ that of RF (299.8 $\mathrm{tC} \mathrm{ha}^{-1}$ ) in 2006 (Fig. 7a). 


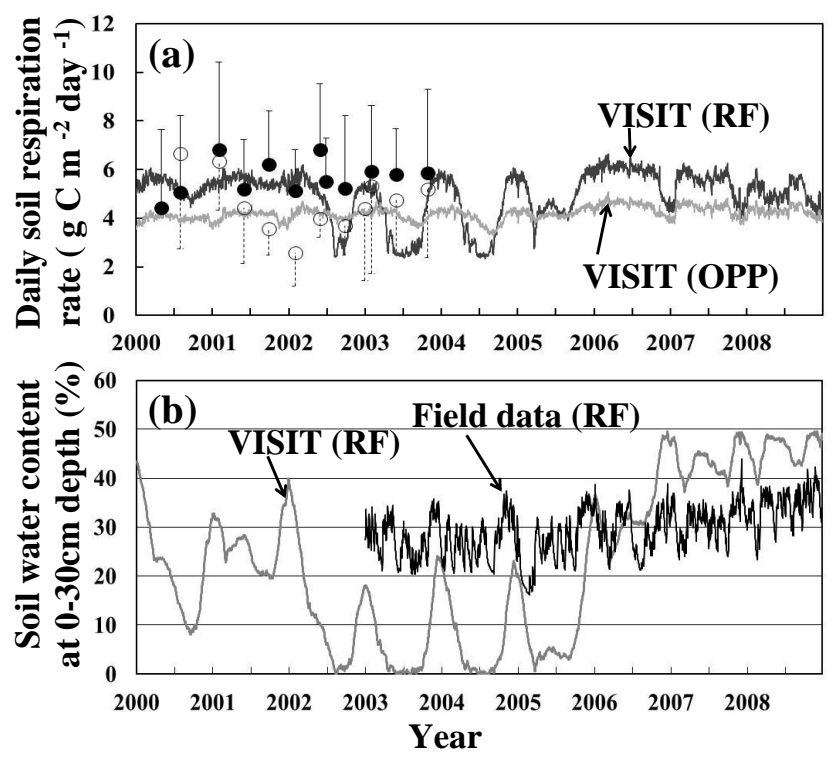

Fig. 8. Comparisons of the VISIT model simulation and field measurements of (a) soil respiration rates (SR) in the rainforest (RF) and oil palm plantation (OPP) from 2000 to 2004 and (b) daily mean soil water content at 0 - to $30-\mathrm{cm}$ depth in RF from 2003 to 2008. In (a), model simulation for RF (bold line), model simulation for OPP (gray line), observed mean SR in RF (filled circles), observed mean SR in OPP (open circles); error bars show the standard deviation $(n=16)$. See Adachi and Koizumi (2009) for field measurements. In (b), field observation from Kosugi et al. (2009) (bold line) and VISIT model estimates in RF (gray line).

\subsection{Validation of the temporal variation on SR, soil water content and GPP}

Figure 8a shows the seasonal variation in SR estimated using the VISIT model and field data from RF and OPP. According to the field data, the spatial variation in SR was greater than the seasonal variation. Adachi et al. (2005) reported that the spatial variation in SR in RF and OPP was larger than the temperate ecosystems, and the coefficient of variation for SR was $43 \%$ in RF and $46 \%$ in OPP. Moreover, the estimated seasonal variation of SR was less than that observed in the field. The estimated annual SR was similar to that of field observations (Table 4), but the spatial variation in SR was not considered in the VISIT model. The second disturbance of replanting oil palms might have caused the decrease in observed SR from 2001 to 2002 in OPP (Fig. 8a); however, the VISIT model cannot consider the process of the second disturbance. The SR and soil water content in RF estimated by the VISIT model was lower than that measured in the field from 2003 to 2005 (Fig. 8), mainly because precipitation based on NCEP/NCAR data tended to be low during this period (Fig. 4).

A comparison of the VISIT model estimates with MODIS data showed that the seasonal variation range of GPP in DEF

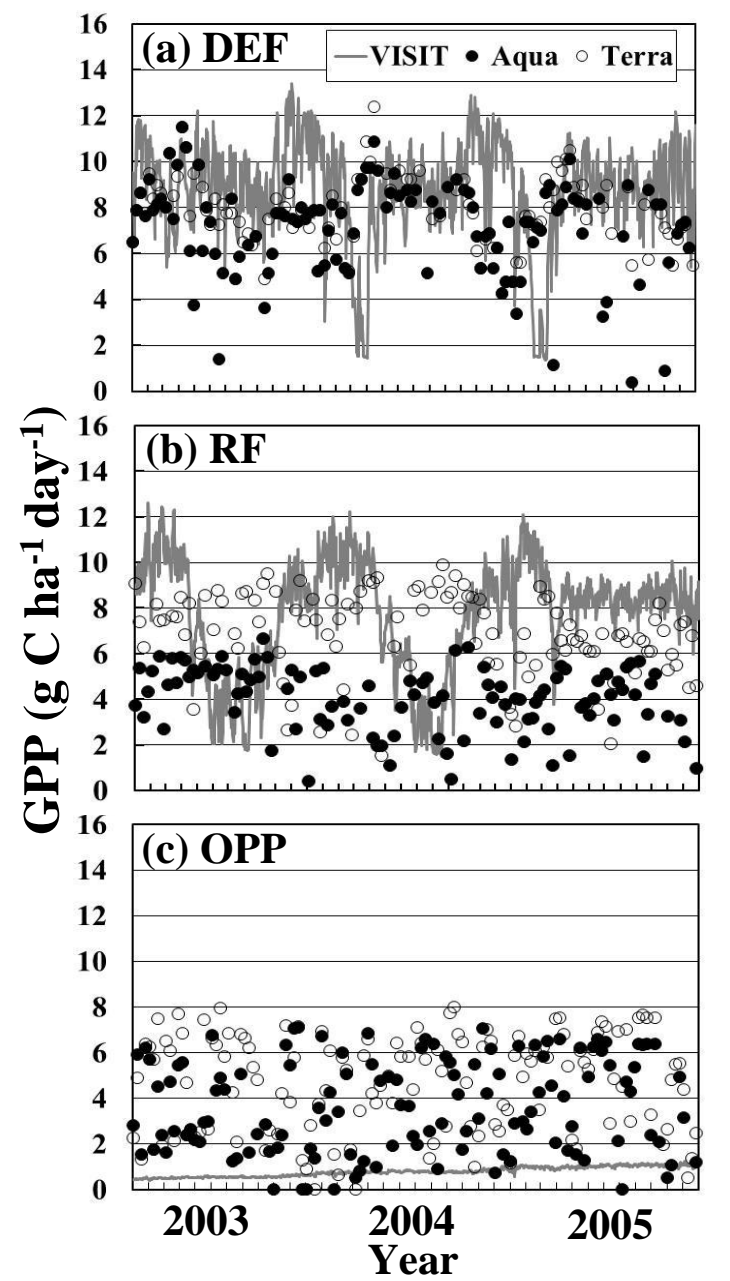

Fig. 9. Seasonal variations in gross primary production (GPP) based on satellite observations (Aqua and Terra MODIS values) and the VISIT model simulation in (a) the dry evergreen forest (DEF) in Thailand, and (b) the rainforest (RF) in Malaysia, and (c) the oil palm plantation (OPP) in Malaysia. Because oil palm seedlings were replanted in 2002 for second rotation in OPP, the disturbance event from forest to oil palm plantation in the VISIT model was set for 2001 .

was more similar to the data gathered by the Terra satellite than that from the Aqua satellite (Fig. 9a). The Aqua satellite data of GPP was lower than that from Terra satellite in RF (Fig. 9b). The Terra and Aqua GPP data at OPP varied widely, but the estimated GPP by the VISIT model was consistently lower than the MODIS observation (Fig. 9c).

\section{Discussion}

\subsection{Comparison of the two primary forests}

The observed aboveground biomass in DEF $\left(226.3 \mathrm{tC} \mathrm{ha}^{-1}\right)$ and RF $\left(201.5 \mathrm{tCha}^{-1}\right)$ indicate that tropical forests of 
Southeast Asia are among the most C-abundant ecosystems in the world, surpassing Amazonian rainforest (161.4 $\mathrm{tCha}^{-1}$; Malhi et al., 2006). The model simulation results were consistent with field data in RF, except for the NEP (Table 4). However, the aboveground biomass estimated by the VISIT model was about $71 \%$ of the field measurement in DEF. The underestimation of aboveground biomass in DEF would be due to the relationship between annual GPP and precipitation in the VISIT model (Fig. 6). Based on soil $\mathrm{C}$ content and bulk density measured in the field (Adachi et al., 2006; Yamashita et al., 2010; Table 2), soil organic $\mathrm{C}$ at $5-\mathrm{cm}$ depth was estimated as $13.0 \mathrm{tCha}^{-1}$ in DEF, which was higher than the estimate of $10.8 \mathrm{tCha}^{-1}$ in RF. But the results of the VISIT model showed the opposite trend: in 2008 the soil $\mathrm{C}$ stocks (litter and humus) were $75.6 \mathrm{tCha}^{-1}$ in RF and $74.7 \mathrm{tC} \mathrm{ha}^{-1}$ in DEF. Thus, field measurements indicate that the $\mathrm{C}$ budget and stock in DEF were larger than those in RF, but the VISIT model tended to underestimate those in DEF.

The seasonal mean light-saturated photosynthetic rates were formulated by functions of temperature, $\mathrm{CO}_{2}$ level, air humidity and soil water (Ito and Oikawa, 2002), and these rates used in the VISIT model were 13.1 and $12.8 \mu \mathrm{mol} \mathrm{m}{ }^{-2} \mathrm{~s}^{-1}$ in DEF and RF, respectively, and these rates are an important factor in estimating the GPP. Ishida et al. (2006) reported that the maximum photosynthetic rate in dry evergreen forest differs according to tree species, leaf maturity and the wet and dry seasons, ranging from 4.6 to $10.7 \mu \mathrm{mol} \mathrm{m}^{-2} \mathrm{~s}^{-1}$ in the dry season and from 8.6 to $12.9 \mu \mathrm{mol} \mathrm{m}{ }^{-2} \mathrm{~s}^{-1}$ in the wet season. Kosugi et al. (2009) reported that the maximum photosynthetic rate in RF was less than $10 \mu \mathrm{mol} \mathrm{m}{ }^{-2} \mathrm{~s}^{-1}$. Although the model parameter of maximum photosynthetic rate was higher than these observed values, the simulated aboveground biomass values were smaller than the field measurements at both sites. Therefore, the underestimation of aboveground biomass could be due to higher respiration rates or turnover rates used in the model.

Estimated NEP was not consistent with field data in both DEF and RF. Ohtsuka et al. (2009) reported that the difference in NEP between the biometric method and eddycovariance method was $\pm 2 \mathrm{tC} \mathrm{ha}^{-1} \mathrm{yr}^{-1}$ in a cool-temperate deciduous broad-leaved forest. Saleska et al. (2003) reported that in Amazonian rainforest the observed seasonal pattern of NEE was opposite the simulated pattern, despite the proper precipitation pattern being used in the models. Therefore, in the present study the difference in NEP between the model simulation and field observation was within the acceptable range. On the other hand, the annual precipitation influenced annual GPP in RF (Fig. 6), this result suggested that meteorological data was also important to accuracy evaluation.

Based on the comparison of the VISIT model estimates with MODIS data, the maximum GPP rate in DEF was higher than that in RF (Fig. 9a, b). In RF, the GPP rate showed a large difference between the results based on Terra versus Aqua data due to the formation of cumulus clouds before the Aqua overpass (Miettinen and Liew, 2008). In a temperate forest, Ito (2010b) compared VISIT model estimates with MODIS data of leaf area index, however, the MODIS-estimated LAI had a large variation during the monsoon rainy season. The MODIS-estimated LAI in the present study sites also had a large variation (data not shown), and this result could be one reason why there were large differences between the results of VISIT model and MODIS estimations. The direct distance from OPP and the edge of RF was about 4-km, and this could cause the inconsistency of GPP data between Terra and Aqua at OPP (Fig. 9c).

More data gathered in tropical regions using various methods are needed to validate and improve the VISIT model simulations. Data obtained by the biometric method, eddycovariance method, and remote sensing have different spatiotemporal scales. For instance, field measurements of SR rates are expected not only to vary temporally due to meteorological conditions, but also to show spatial variation among a limited number of SR chambers.

\subsection{Effect of land-use change to an oil palm plantation on the ecosystem $\mathrm{C}$ budget}

Our findings indicate that the total $\mathrm{C}$ stock and SR in OPP at $30 \mathrm{yr}$ became smaller than that in forest ecosystems (Fig. 7). Although oil palm plantations are structurally simpler than primary forest ecosystems, the agricultural tasks performed by people are expected to engender complexity and make model simulations of this system more difficult. We added the event of leaf harvest and removal to the model in order to more accurately compare the simulated and observed SR rates. The maximum photosynthetic rate was $20 \mu \mathrm{mol} \mathrm{m}^{-2} \mathrm{~s}^{-1}$, it decreased with leaf ages in oil palms (Dufrene and Saugier, 1993). The estimated seasonal mean light-saturated photosynthesis rates by the VISIT model were $11.8 \mu \mathrm{mol} \mathrm{m} \mathrm{m}^{-2} \mathrm{~s}^{-1}$ in OPP, but the reduction of photosynthesis rates induced by leaf senescence was not considered in this model. Oil palm trees are clear-cut and seedlings are replanted at 25- to 30-yr rotations in Southeast Asia (Corley and Tinker, 2003). These events occurred again for the second rotation in OPP in 2001, however, the VISIT model can simulate the event of disturbance and planting of oil palm seedlings only once. The VISIT model needs to improve for evaluation of the $\mathrm{C}$ budget in maintained agricultural management, because the second disturbance was different from first disturbance (e.g., amount of residual debris and its decomposition rate).

The estimated values of soil $\mathrm{C}$ emission after disturbance are expected to be underestimated, however, because the calculation does not account for the acceleration of decomposition at the soil surface due to the change in the radiation budget. In general, the soil surface becomes warmer and dryer after a clear-cut because it receives more direct solar radiation (Ritter et al., 2005). Several studies have shown that 
soil organic matter is sensitive to land-use change in tropical ecosystems (Chaplot et al., 2005; Fujii et al., 2009; MarinSpoitta et al., 2009). Sheng et al. (2010) reported that the temperature sensitivity of SR rates (i.e., the $Q_{10}$ value) was higher in sloping tilled land than in a natural subtropical forest in China. Solomon et al. (2007) found that soil organic $\mathrm{C}$ loss occurred during the first $4 \mathrm{yr}$ after land-use change in a tropical region, and the forest soil was more sensitive to environmental conditions than that of native grasslands. However, Tanaka et al. (2009) reported finding no significant difference in total $\mathrm{C}$ contents among secondary forests and some types of plantations, including trees of different ages in Malaysia. Our field measurements indicated that soil physical parameters change when primary forest is converted to an oil palm plantation (Table 2). Clay content in OPP was lower than that in RF, whereas sand content showed the opposite pattern. Islam and Weil (2000) also reported that land-use change from tropical forest to cropland caused a decrease in silt and clay content. The relationship between clay content and soil organic content was not clear in the worldwide, but clay minerals help to stabilize soil organic matter (McLauchlan, 2006). These results suggest that soil properties would be affected by land-use change, and the VISIT model would develop to consider the relationship between soil characteristics and the productively of ecosystems in the future.

Using the VISIT model and the deforestation rate reported by FAO (2010), the total $\mathrm{C}$ emissions induced by land-use change in Malaysia between 1995 and 2004 was estimated as $16.8 \mathrm{MtC}$. This value was calculated by multiplying the deforestation area and the estimated NEP by VISIT model at every year. This is useful information for managing activities related the Reduce Emissions from Deforestation and Forest Degradation (REDD) initiative. Detecting the effects of landuse change on soil biochemical and physical characteristics requires long-term measurements, however, because it is necessary to examine when and how these soil characteristics change. Unfortunately, we lack sufficient information about how fast soil physical properties are expected to change after disturbances in tropical forests. Published reports and/or opened database are the most important sources of information for model development and validation. For instance, for the present model simulations the following observational data or empirical equations were needed: (1) long-term or short-term change in carbon pools and fluxes (e.g., aboveground biomass, NPP and litter decomposition rate) for the model validation and input data, (2) basic environmental variables (e.g., precipitation, soil water content and soil temperature) for input data, and (3) disturbance history information (e.g., logging and land-use) for model constraint factors. Many black boxes and mechanisms of the matter flow of ecosystems would be more easily understood through the combined use of field observations and model simulations.
Acknowledgements. This research was supported by the Ministry of the Environment, Japan (grant no. A-0801), and by funding to promote creative research at the National Institute for Environmental Studies (grant no. 1010AF001). We thank T. Maeda of the National Institute of Advanced Industrial Science, Mr. S. Panuthai of Department of National Park, and Technology and the AsiaFlux Database (http://asiaflux.yonsei.kr/index.html) for providing the climate data in Sakaerat, Thailand. We also thank T. Nakano of Yamanashi Environmental Studies and K. Yoshimura of the Forestry and Forest Products Research Institute for their help in conducting experiments at Sakaerat.

Edited by: N. Ohte

\section{References}

Adachi, M. and Koizumi, H.: Soil organic carbon dynamics of different land use in Southeast Asia, in: Forest canopies: forest production, ecosystem health and climate conditions, edited by: Creighton, J. D. and Roney, P. J., Nova Science Publishers Inc., New York, NY, USA, 85-101, 2009.

Adachi, M., Bekku, S. Y., Konuma, A., Kadir, W. R., Okuda, T., and Koizumi, H.: Required sample size for estimating soil respiration rates in large areas of two tropical forests and of two types of plantation in Malaysia, Forest Ecol. Manag., 210, 455-459, 2005.

Adachi, M., Bekku, Y. S., Kadir, W. R., Okuda, T., and Koizumi, H.: Differences in soil respiration between different tropical ecosystems, Appl. Soil. Ecol., 34, 258-265, 2006.

Bekku, S. Y., Nakatsubo, T., Kume, A., Adachi, M., and Koizumi, H.: Effect of warming on the temperature dependence of soil respiration rate in arctic, temperate and tropical soils, Appl. Soil. Ecol., 22, 205-210, 2003.

Chapin III, F. S., Woodwell, G. M., Randerson, J. T., Rastetter, E. B., Lovett, G. M., Baldocchi, D. D., Clark, D. A., Harmon, M. E., Schimel, D. S., Valentini, R., Wirth, C., Aber, J. D., Cole, J. J., Goulden, M. L., Harden, J. W., Heimann, M., Howarth, R. W., Matson, P. A., McGuire, A. D., Melillo, J. M., Mooney, H. A., Neff, J. C., Houghton, R. A., Pace, M. L., Ryan, M. G., Running, S. W., Sala, O. E., Schelesinger, W. H., and Schulze, E. D.: Reconciling carbon-cycle concepts, terminology, and methods, Ecosystems, 9, 1041-1050, 2006.

Chaplot, V. A. M., Rumpel, C., and Valentin, C.: Water erosion impact on soil and carbon redistributions within uplands of Mekong River, Global Biogeochem. Cy., 19, GB4004, doi:10.1029/2005GB002493, 2005.

Corley, R. H. V. and Tinker, P. B. (Eds.): The oil palm, Blackwell Science, Oxford, UK, 2003.

Cramer, W., Bondeau, A., Schaphoff, S., Lucht, W., Smith, B., and Sitch, S.: Tropical forests and the global carbon cycle: impacts of atmospheric carbon dioxide, climate change and rate of deforestation, Philos. T. R. Soc. Lon. B, 359, 331-343, 2004.

Dufrene, E. and Saugier, B.: Gas exchange of oil palm in relation to light, vapour pressure deficit, temperature and leaf age, Funct. Ecol., 7, 97-104, 1993. 
Fitzherbert, E. B., Struebig, M. J., Morel, A., Danielsen, F., Brühl, C. A., Donald, P. F., and Phalan, B.: How will oil palm expansion affect biodiversity?, Trends Ecol. Evol., 23, 538-545, 2008.

Food and Agriculture Organization (FAO): Global Forest Resources Assessment 2010, Country report, Food and Agriculture Organization of the United Nations, Rome, Italy, 2010.

Fujii, K., Funakawa, S., Hayakawa, C., Sukartiningsih, and Kosaki, T.: Quantification of proton budgets in soil of cropland and adjacent forest in Thailand and Indonesia, Plant Soil, 316, 241-255, 2009.

Hillel, D. (Ed.): Environmental Soil Physics, Elsevier, New York, NY, USA, 1998.

Hirata, R., Saigusa, N., Yamamoto, S., Ohtani, Y., Ide, R., Asanuma, J., Gamo, M., Hirano, T., Kondo, H., Kosugi, Y., Li, S.G., Nakai, Y., Takagi, K., Tani, M., and Wang, H.: Spatial distribution of carbon balance in forest ecosystems across East Asia, Agr. Forest Meteorol., 148, 761-775, 2008.

Hoshizaki, H., Niiyama, K., Kimura, K., Yamashita, T., Bekku, Y., Okuda, T., Quah, E. S., and Nur Supardi, M. N.: Recent biomass change in relation to stand dynamics in a lowland tropical rain forest, Pasoh Forest Reserve, Malaysia, Ecol. Res., 19, 357-363, 2004.

Houghton, R. A.: The annual net flux of carbon to the atmosphere from changes in land use 1850-1990, Tellus, B51, 298-313, 1999.

Houghton, R. A., Hobbie, J. E., Melillo, J. M., Moore, B., Peterson, B. J., Shaver, G. R., and Woodwell, G. M.: Changes in the carbon content of terrestrial biota and soils between 1860 and 1980: a net release of $\mathrm{CO}_{2}$ to the atmosphere, Ecol. Monogr., 53(3), 235262, 1983.

Huang, M., Asner, G. P., Keller, M., and Berry, J. A.: An ecosystem model for tropical forest disturbance and selective logging, J. Geophys. Res., 113, G01002, doi:10.1029/2007JG000438, 2008.

Inatomi, M., Ito, A., Ishijima, K., and Murayama, S.: Greenhouse gas budget of a cool-temperate deciduous broad-leaved forest in Japan estimated using a process-based model, Ecosystems, 13, 472-483, 2010.

Intergovernmental Panel on Climate Change (IPCC): Climate change 2007: the physical science basis, edited by: Solomon, S., Qin, D., Manning, M., Chen, Z., Marquis, M., Averyt, K. B., Tignor, M., and Miller, H. L., Cambridge University Press, Cambridge, UK, 2007.

Ishida, A., Diloksumpun, S., Ladpala, P., Staporn, D., Panuthai, S., Gamo, M., Yazaki, K., Ishizuka, M., and Puangchit, L.: Contrasting seasonal leaf habits of canopy trees between tropical drydeciduous and evergreen forests in Thailand, Tree Physiol., 26, 643-656, 2006.

Islam, K. R. and Weil, R. R.: Land use effects on soil quality in a tropical forest ecosystem of Bangladesh, Agr. Ecosyst. Environ., 79, 9-16, 2000.

Ito, A.: Changing ecophysiological processes and carbon budget in East Asian ecosystems under near-future changes in climate: implications for long-term monitoring from a process-based model, J. Plant Res. 123, 577-588, 2010a.

Ito, A.: Evaluation of the impacts of defoliation by tropical cyclones on a Japanese forest's carbon budget using flux data and a process-based model, J. Geophys. Res.-Biogeo., 115, G04013, doi:10.1029/2010JG001314, 2010b.

Ito, A. and Oikawa, T.: A simulation model of the carbon cycle in land ecosystems (Sim-CYCLE): a description based on dry matter production theory and plot-scale validation, Ecol. Model., 151, 143-176, 2002.

Ito, A., Saigusa, N., Murayama, S., and Yamamoto, S.: Modeling of gross and net carbon dioxide exchange over a cool-temperate deciduous broad-leaved forest in Japan: analysis of seasonal and interannual change, Agr. Forest Meteorol., 134, 122-134, 2005.

Ito, A., Muraoka, H., Koizumi, H., Saigusa, N., Murayama, S., and Yamamoto, S.: Seasonal variation in leaf properties and ecosystem carbon budget in a cool-temperate deciduous broad-leaved forest: simulation analysis at Takayama site, Japan, Ecol. Res., 21, 137-149, 2006.

Kanzaki, M., Kawaguchi, H., Kiyohara, S., Kajiwara, T., Kaneko, T., Ohta, S., Sangpalee, W., and Wachrinrat, C.: Long-term study on the carbon storage and dynamics in a tropical seasonal evergreen forest of Thailand, in: Tropical forestry change in a changing world, FORTROP II International Conference, 17-20 November 2008, edited by: Pirangchit, L. and Diloksumpun, S., Royal Forest Department and Kasetsart University, Bangkok, Thailand, 37-51, 2009.

Kato, T., Ito, A., and Kawamiya, M.: Multiple temporal scale variability during the twentieth century in global carbon dynamics simulated by a coupled climate-terrestrial carbon cycle model, Clim. Dynam., 32, 901-923, 2009.

Kistler, R., Kalnay, E., Collins, W., Saha, S., White, G., Woollen, J., Chelliah, M., Ebisuzaki, W., Kanamitsu, M., Kousky, V., van den Dool, H., Jenne, R., and Fiorino, M.: The NCEP-NCAR 50-year reanalysis: monthly means CD-ROM and documentation, Bull. Am. Meteorol. Soc., 82, 247-267, 2001.

Kosugi, Y., Takanashi, S., Ohkubo, S., Matsuo, N., Tani, M., Mitani, T., Tsutsumi, D., and Nik, A. R.: $\mathrm{CO}_{2}$ exchange of a tropical rainforest at Pasoh in Peninsular Malaysia, Agr. Forest Meteorol., 148, 439-452, 2008.

Kosugi, Y., Takanashi, S., Matsuo, N., and Nik, A. R.: Middy depression of leaf $\mathrm{CO}_{2}$ exchange within the crown of Dipterocarpus sublamellatus in a lowland dipterocarp forest in Peninsular Malaysia, Tree Physiol., 29, 505-515, 2009.

Malhi, Y., Wood, D., Baker, T. R., Wright, J., Phillips, O. L., Cochrane, T., Meir, P., Chave, J., Almeida, S., Arroyo, L., Higuchi, N., Killeen, T. J., Laurance, S. G., Laurance, W. F., Lewis, S. L., Monteagudo, A., Neill, D. A., Vargas, P. N., Pitman, N. C. A., Quesada, C. A., Salomao, R., Silva, J. N. M., Lezama, A. T., Terborgh, J., Martinez, R. V., and Vinceti, B.: The regional variation of aboveground live biomass in old-growth Amazonian forests, Glob. Change Biol., 12, 1107-1138, 2006.

Malhi, Y., Roberts, J. T., Betts, R. A., Killeen, T. J., Li, W., and Nobre, C. A.: Climate change, deforestation, and the fate of the Amazon, Science, 319, 169-172, 2008.

Manokaran, N., Quah, E. S., Ashton, P. S., LaFrankie, J. V., Nur Supardi, M. N., Ahmad, W. M. S. W., and Okuda, T.: Pasoh forest dynamics plot, Peninsular Malaysia, in: Tropical forest diversity and dynamism, edited by: Losos, E. C. and Leigh, J. E. G., The University of Chicago Press, Chicago, USA, 585-598, 2004.

Marin-Spiotta, E., Silver, W., Swanston, C., and Ostertag, R.: Soil organic matter dynamics during 80 years of reforestation of tropical pastures, Glob. Change Biol., 15, 1584-1597, 2009.

McGuire, A. D., Sitch, S., Clein, J. S., Dargaville, R., Esser, G., Foley, J., Heimann, M., Joos, F., Kaplan, J., Kicklighter, D. W., 
Meier, R. A., Melillo, J. M., Moore III., B., Prentice, I. C., Ramankutty, N., Reichenau, T., Schloss, A., Tian, H., Williams, L. J., and Wittenberg, U.: Carbon balance of the terrestrial biosphere in the twentieth century: analyses of $\mathrm{CO}_{2}$, climate and land use effects with four process-based ecosystem models, Glob. Change Biol., 15, 183-206, 2001.

McLauchlan, K.: The nature and longevity of agricultural impacts on soil carbon and nutrients: a review, Ecosystems, 9, 13641382, 2006.

Melling, L., Goh, K. J., Constance, B., and Hatano, R.: Carbon flow and budget in a young mature oil palm agroecosystem on deep tropical peat, Planter, 84, 21-25, 2008.

Miettinen, J. and Liew, S. C.: Comparison of multitemporal compositing methods for burnt area detection in Southeast Asian conditions, Int. J. Remote Sens., 29, 1075-1092, 2008.

Oak Ridge National Laboratory Distributed Active Archive Center (ORNL DAAC): MODIS subsetted land products, Collection 5, available at: http://daac.ornl.gov/MODIS/modis.html from ORNL DAAC, Oak Ridge, Tennessee, USA, last access: 28 July 2010.

Ohtsuka, T., Saigusa, N., and Koizumi, H.: On linking multiyear biometric measurements of tree growth with eddy covariancebased net ecosystem production, Glob. Change Biol., 15, 10151024, 2009.

Poulter, B., Aragao, L., Heyder, U., Gumpenberger, M., Heinke, J., Langerwisch, F., Rammig, A., Thonicke, K., and Cramer, W.: Net biome production of the Amazon Basin in the 21st century, Glob. Change Biol., 16, 2062-2075, 2010.

Ramankutty, N., Gibbs, H. K., Achard, F., Defries, R., Foley, J. A., and Houghton, R. A.: Challenges to estimating carbon emissions from tropical deforestation, Glob. Change Biol., 13, 51-66, 2007.

Ritter, E., Dalsgaard, L., and Einhorn, K. S.: Light, temperature and soil moisture regimes following gap formation in a semi-natural beech-dominated forest in Denmark, Forest Ecol. Manag., 206, 15-33, 2005.

Sakurai, K., Tanaka, S., Ishizuka, S., Kanzaki, M.: Differences in soil properties of dry evergreen and dry deciduous forests in the Sakaerate environmental research station, Tropics, 8, 61-80, 1998.

Saleska, S. R., Miller, S. D., Matross, D. M., Goulden, M. L., Wofsy, S. C., da Rocha, H. R., de Camargo, P. B., Crill, P., Daube, B. C., de Freitas, H. C., Hutyra, L., Keller, M., Kirchhoff, V., Menton, M., Munger, J. W., Pyle, E. H., Rice, A. H., and Silva, H.: Carbon in Amazon forests: unexpected seasonal fluxes and disturbance-induced losses, Science, 302, 1554-1557, 2003.
Shevliakova, E., Pacala, S. W., Malyshev, S., Hurtt, G. C., Milly, P. C. D., Caspersen, J. P., Sentman, L. T., Fisk, J. P., Wirth, C., and Crevoisier, C.: Carbon cycling under 300 years of land use change: importance of the secondary vegetation sink, Global Biogeochem. Cy., 23, GB2022 doi:10.1029/2007GB003176, 2009.

Sheng, H., Yang, Y., Yang, Z., Chen, G., Xie, J., Guo, J., and Zou, S.: The dynamic response of soil respiration to land-use changes in subtropical China, Glob. Change Biol., 16, 1107-1121, 2010.

Solomon, D., Lehmann, J., Kinyangi, J., Amelung, W., Lobe, I., Pell, A., Riha, S., Ngoze, S., Verchot, L., Mbugua, D., Skjemstad, J., and Schäfer, T.: Long-term impacts of anthropogenic perturbations on dynamics and speciation of organic carbon in tropical forest and subtropical grassland ecosystems, Glob. Change Biol., 13, 511-530, 2007.

Stone, R.: Can palm oil plantations come clean?, Science, 317, 1491, doi:10.1126/science.317.5844.1491, 2007.

Tanaka, S., Tachibe, S., Wasli, M. E. B., Lat, J., Seman, L., Kendawang, J. J., Iwasaki, K., and Sakurai, K.: Soil characteristics under cash crop farming in upland areas of Sarawaku, Malaysia, Agr. Ecosyst. Environ., 129, 293-301, 2009.

van der Werf, G. R., Morton, D. C., DeFries, R. S., Olivier, J. G. J., Kasibhatla, P. S., Jackson, R. B., Collatz, G. J., and Randerson, J. T.: $\mathrm{CO}_{2}$ emissions from forest loss, Nat. Geosci., 2, 737-738, 2009.

Yamashita, T., Kasuya, N., Wan, R. K., Suhaimi, W. C., Quah, E. S., and Okuda, T.: Soil and belowground characteristics of Pasoh Forest Reserve, in: Pasoh - Ecology of a Lowland Rain Forest in Southeast, edited by: Okuda, T., Manokaran, Y., Matsumoto, Y., Niiyama, K., Thomas, S. C., and Ashton, P. S., Springer-Verlag, Tokyo, Japan, 89-109, 2003.

Yamashita, N., Ohta, S., Sase, H., Luangjame, J., Visaratana, T., Kievuttinon, B., Garivait, H., and Kanzaki, M.: Seasonal and spatial variation of nitrogen dynamics in the litter and surface soil layers on a tropical dry evergreen forest slope, Forest Ecol. Manag., 259, 1502-1512, 2010.

Yashiro, Y., Kadir, W. R., Adachi, M., Okuda, T., and Koizumi, H.: Emission of nitrous oxide from tropical forest and plantation soils in Peninsular Malaysia, Tropics, 17, 17-23, 2007. 